\title{
PRZESTRZENNO-CZASOWA ANALIZA SKUPIEŃ W OCENIE WRAŻLIWOŚCI NA KRYZYS UNIJNYCH REGIONÓW SZCZEBLA NUTS 2 W OBSZARACH: GOSPODARKA, RYNEK PRACY I GOSPODARSTWA DOMOWE - ANALIZA PORÓWNAWCZA WYNIKÓW KLASYFIKACJI ${ }^{2}$
}

\begin{abstract}
W artykule porównano wyniki przestrzenno-czasowej analizy skupień przeprowadzonej osobno w poszczególnych obszarach wrażliwości na kryzys. Obszary wrażliwości na kryzys proponowane w ocenianych klasyfikacjach to: gospodarka, regionalny rynek pracy i gospodarstwa domowe.

Metoda klasyfikacji zastosowana w porównywanych podejściach to klasyfikacja dynamiczna, w której obiekty badania w każdym roku traktowane są jako odrębne jednostki taksonomiczne. Obiekty badania stanowiły regiony Unii Europejskiej szczebla NUTS 2. Okres analizy obejmował lata 2005-2011, a po ustaleniu dla wielu zmiennych ich tempa zmian klasyfikacje $\mathrm{w}$ poszczególnych obszarach wrażliwości przeprowadzano na podstawie zmiennych z lat 2006-2011.

Do porównaniawyników uzyskanych klasyfikacji wykorzystano zaproponowaną przez A. Sokołowskiego metodę porównywania wyników podziału zbioru skończonego, w której współczynnik zgodności podziałów - unormowany w przedziale $[0 ; 1]$ - przyjmuje tym większe wartości, im podziały są bardziej podobne. Oceniono podobieństwo podziałów zarówno w ujęciu każdego roku (dla wskaźników zgodności podziałów przedstawiono także trendy), a także w ujęciu łącznym (zdynamizowanym).Otrzymane wyniki wskazują na znaczące podobieństwa uzyskanych klasyfikacji. W ujęciu dynamicznym są to wskaźniki na poziomie $0,52 \mathrm{w}$ obszarach regionalny rynek pracy i gospodarstwa domowe, do 0,67 dla obszarów gospodarka i regionalny rynek pracy.Również w porównaniach przeprowadzonych dla każdego roku najniższy wskaźnik podobieństwa podziału był na poziomie 0,52 (rynek pracy i gospodarka w roku 2009), a najwyższy - 0,72 (rynek pracy i gospodarstwa domowe w 2006).

Słowa kluczowe: przestrzenno-czasowa analiza skupień, obszary wrażliwości, kryzys ekonomiczny, regiony NUTS 2
\end{abstract}

\section{WPROWADZENIE}

Identyfikacja obszarów wrażliwości na kryzys ekonomiczny regionów i poszukiwanie grup regionów o podobnych trajektoriach zmian w okresie gospodarczych turbulencji stanowiąważne zagadnienia badawcze.To interesująca przestrzeń badawcza stwarzająca możliwośćproponowania różnorodnych podejść metodologicznych. Jako jeden $\mathrm{z}$

${ }^{1}$ Dr hab. Małgorzata Markowska, Wydział Ekonomii, Zarządzania i Turystyki, Uniwersytet

Ekonomiczny, Wrocław, e-mail: malgorzata.markowska@ue.wroc.pl

${ }^{2}$ Projekt finansowany ze środków NCN (DEC-2013/09/B/HS4/00509). 
determinantów radzenia sobie regionów z kryzysem można wskazać inteligentny rozwój, którego filary to: innowacyjność, kreatywne regiony i inteligentna specjalizacja.

Celem artykułu jest ocena zgodności wyników klasyfikacji dynamicznejregionów UE szczebla NUTS 2 w trzech obszarach wrażliwości na kryzys ekonomiczny: gospodarka (G), rynek pracy (RP) i gospodarstwa domowe (GD) z wykorzystaniem metody porównywania wyników podziału zbioru skończonego.

\section{IDENTYFIKACJA OBSZARÓW WRAŻLIWOŚCI NA KRYZYS EKONOMICZNY REGIONÓW}

W propozycji podejścia metodologicznego do identyfikacji zależności zachodzących w przestrzeni regionalnej między inteligentnym rozwojem a wrażliwością na kryzys ekonomiczny bazuje się na takich metodach badawczych jak: wielowymiarowa analiza statystyczna, metody klasyfikacji oraz metody modelowania ekonometrycznego, w tym modele panelowe i logitowe. W skrócie koncepcję można przedstawić w następujących etapach $]^{3}$ :

I. Opracowanie metodologicznych podstaw badawczych, w tym: opracowanie miary wrażliwości na kryzys ekonomiczny w wymiarze regionalnym; wskazanie metod współczesnej ekonometrii i wielowymiarowej analizy danych do badania zależności między inteligentnym rozwojem a przejawami kryzysu ekonomicznego w wymiarze regionalnym.

II. Wskazanie obiektów badania i identyfikacja możliwości pozyskania danych w bazach danych statystycznych służącychdo budowy mierników ilustrujących rozwój inteligentny i wrażliwość na kryzys ekonomiczny. Budowabazy danych regionalnych z wykorzystaniem do uzupełniania brakujących informacji metod statystycznych.

III. Klasyfikacja dynamiczna unijnych regionów NUTS 2 zewzględuna:poziom rozwoju inteligentnego $\mathrm{w}$ europejskiej przestrzeni regionalnej; stopień wrażliwości na kryzys ekonomiczny $\mathrm{w}$ regionach ( $\mathrm{w}$ tym $\mathrm{w}$ obszarach wrażliwości); poziom rozwoju inteligentnego i stopień wrażliwości na kryzys ekonomiczny w regionach Unii Europejskiej (UE)-klasyfikacja zintegrowana; budowa macierzy przejścia regionów między klasami.

IV. Budowa modeli ekonometrycznych identyfikujących związki między rozwojem inteligentnym a wrażliwością na kryzys ekonomiczny regionów UE.

V. Identyfikacja miejsca polskich regionów na mapie europejskiej przestrzeni regionalnej ze względu na wartości charakterystyk wybranych do oceny inteligentnego rozwoju i wrażliwości na kryzys ekonomiczny w grupach regionów.

W drugim etapie, mając na uwadze konieczność realizacji dalszych etapów procedury badawczej, wskazano na potrzebę budowy bazy danych w kilku obszarach oceny na szczeblu regionalnym. Oceny możliwości realizacji propozycji procedury pomiaru i identyfikacjiwrażliwości na kryzys ekonomiczny w europejskich regionach na podstawie

\footnotetext{
${ }^{3}$ D. Strahl, A. Sokołowski, Propozycja podejścia metodologicznego do oceny zależności między inteligentnym rozwojem a wrażliwościa na kryzys ekonomiczny $w$ wymiarze regionalnym, [w:] Problemy rozwoju regionalnego i lokalnego, red. E. Sobczak, B. Bal-Domańska, M. Obrębalski, Prace Naukowe Uniwersytetu Ekonomicznego we Wrocławiu nr 331, Wrocław 2014, s. 181-190.
} 
przeglądu zasobów baz danych Eurostatu w zakresie informacji na szczeblu NUTS 2 dokonano w pracy Markowskiej, Strahl ${ }^{4}$.

Na podstawie tych wstępnych badań oraz studiów literaturowych ${ }^{5}$ ustalono, że zakres tematyczny bazy danych powinien obejmować w ujęciu dynamicznym:

- zmiany na rynku pracy (podaż i popyt);

- zmiany w gospodarce [produkt krajowy brutto (PKB), wartość dodana brutto(WDB), inwestycje, demografia firm, wynagrodzenia, nakłady na działalność badawczo-rozwojową $(\mathrm{B}+\mathrm{R})]$;

- sytuacja gospodarstw domowych (dochody).

W konsekwencji w przedstawionej procedurze oceny zaproponowano trzy obszary wrażliwości na kryzys ekonomiczny regionów6

- gospodarka;

- regionalny rynek pracy;

- gospodarstwa domowe.

W obszarze gospodarka regionu na wstępnej liście zmiennych były:PKB w mln PPS (Purchasing Power Standard), zmiany w PKB, PKB per capita w PPS, zmiany w PKB per capita, nakłady na środki trwałe (mln euro), tempo zmian nakładów na środki trwałe, inwestycje (nakłady inwestycyjne w mln euro), tempo zmian nakładów inwestycyjnych wydajność pracy (PKB/pracującego), wartość dodana brutto, nakłady na B+R jako odsetekregionalnego PKB.

Dla obszaru regionalny rynek pracy zaproponowano wstępnie następującą listę zmiennych: liczba pracujących w grupie wiekowej 15-64 lat w tys., zmiany liczby pracujących w grupie wiekowej 15-64 lata w tys., stopa zatrudnienia w grupie wiekowej 15-64 lat, stopa zatrudnienia w grupie wiekowej 15-24 lat, stopa zatrudnienia w grupie wiekowej 25-64 lat, stopa bezrobocia w grupie wiekowej 15 i więcej lat, zmiany stopy bezrobocia, udział pracujących w sektorach gospodarki (rolnictwo, przemysł, usługi), zmiany udziału pracujących w sektorach gospodarki (rolnictwo, przemysł, usługi).

Do ilustracji sytuacji w obszarze gospodarstw domowych wybrano zmienne: dochód rozporządzalny gospodarstw domowych w PPS, wynagrodzenia pracowników i ich tempa zmian.

${ }^{4}$ M. Markowska, D. Strahl, Sensitivity to economiccrisis of the EU regions - assessment of measurementpossibilities, "Zeszyty Naukowe Uniwersytetu Ekonomicznego w Krakowie" 2015 (w druku).

${ }^{5}$ L. Briguglio, G. Cordina, N. Farrugia, S. Vella, Economic Vulnerability and Resilience: Concepts and Measurements. Oxford Development Studies" 2009/37, 3, s. 229-247; G. Masik, Uwarunkowania $i$ instrumenty wspierajace odporność gospodarcza miast i regionów,referatna konferencji „Polityka miejska. Wyzwania, doświadczenia, inspiracje”, Warszawa 25-26.06.2013; P.Churski, A. Borowczak, M. Dolata, J. Dominiak, J. Hauke, B. Konecka-Szydłowska, R. Perdał, Rekomendacje dotyczace zasobów informacyjnych oraz wskaźnikowania zjawisk społeczno-ekonomicznych $w$ badaniach regionalnych, Biuletyn KPZK PAN, Warszawa 2014; Wrażliwość polskich regionów na wyzwania wspótczesnej gospodarki. Implikacje dla polityki rozwoju regionalnego, red. K. Gawlikowska-Hueckel, J. Szlachta, Oficyna a Wolters Kluwer business, Warszawa 2014; M. Markowska, Ocena zależności między rozwojem inteligentnym a odpornościa na kryzys ekonomiczny w wymiarze regionalnym - przeglad badań,[w:] Gospodarka regionalna w teorii i praktyce, red. D. Strahl, A. Raszkowski i D. Głuszczuk, Prace Naukowe Uniwersytetu Ekonomicznego we Wrocławiu nr 333, Wrocław 2014, s. 22-32.

${ }^{6}$ D. Strahl, A. Sokołowski, Propozycja podejścia metodologicznego do oceny zależności między inteligentnym rozwojem a wrażliwościa na kryzys ekonomiczny $w$ wymiarze regionalnym,[w:] Problemy rozwoju regionalnego i lokalnego, red. E. Sobczak, B. Bal-Domańska, M. Obrębalski, Prace Naukowe Uniwersytetu Ekonomicznego we Wrocławiu nr 331, Wrocław 2014, s. 181-190. 


\section{METODA PORÓWNYWANIA WYNIKÓW PODZIALU ZBIORU SKOŃCZONEGO}

W literaturze zaproponowano wiele miar porównywania wyników podziału zbioru skończonego. Sokołowski i in. ${ }^{7}$ w opracowaniu porównawczym omówili niemal 50 takich miar $^{8}$. Można je podzielić na trzy grupy: (1) wykorzystujące zliczaniepar, (2) wykorzystujące wspólne części skupień oraz (3) oparte na teorii informacji. Niektóre miary, identyczne co do idei konstrukcji, były proponowane niezależnie przez różnych autorów. W tej pracy zdecydowano się wykorzystać prostą miarę łączącą własności pierwszej i drugiej grupy.

Kolejne etapy metody można przedstawić następująco 9 :

1. Należy stworzyć binarną macierz przyporządkowania B1 opisującą pierwszy podział. Element $(i, j)$ jest równy 1 , jeżeli obiekty o numerach $\mathrm{i}$ oraz $\mathrm{j}$ są $\mathrm{w}$ tym samym podzbiorze, zero, jeżeli są w różnych. Macierz jest kwadratowa i ma rozmiar $(n \times n)$, gdzie $n$ jest liczbą obiektów.

2. Należy stworzyćbinarną macierz przyporządkowania B2 dla drugiego podziału w taki sam sposób jak dla pierwszego. Liczba grup w podziałach nie musi być taka sama.

3. Należy stworzyćmacierz $\mathbf{B}=\mathbf{B} 1+\mathbf{B 2}$. Ma ona elementy $0,1,2$. Jedynka świadczy o tym, że para obiektówzostała różnie przyporządkowana w dwóch porównywanych przedziałach.

4. Współczynnik podobieństwa (zgodności) podziałów to (1):

$$
W=1-\frac{z_{1}}{n(n-1)} \text {. }
$$

Miara przyjmuje wartości z przedziału [0,1]. Im wyższa wartość, tym podziały są bardziej podobne. Wartość zero występuje wtedy, gdy w jednym podziale jest $n$ grup (każdy obiekt w swojej osobnej grupie), a w drugim wszystkie obiekty są w jednej grupie. Wartość 1 występuje wtedy, gdy podziały są identyczne.

\section{WYNIKI KLASYFIKACJI DYNAMICZNEJ W OBSZARACH WRAŻLIWOŚCI NA KRYZYS - KRÓTKA CHARAKTERYSTYKA}

Jako zakres czasowy prowadzonych analiz w poszczególnych obszarach wrażliwości przyjętolata 2005-2011, przy czym w klasyfikacji, zewzględuna konieczność obliczenia temp, było to w konsekwencji sześć lat (2006-2011).Przedstawione wcześniej wstępne listy zmiennych zostały, po uwzględnieniu dostępności relatywnie kompletnych szeregówdanych dla unijnych regionów szczebla NUTS 2, skrócone do list wskazanych w kolejnych częściach.

\footnotetext{
${ }^{7}$ A. Sokołowski, S. Denkowska, M. Salamaga, K. Fijorek, Rozkłady miar podobieństwa podziału zbioru skończonego, Uniwersytet Ekonomiczny w Krakowie, Kraków 2010 (maszynopis)

${ }^{8}$ Innepraceprzeglądowe to naprzykład: P. Arabie, L. Hubert, Comparing Partitions, „Journal of Classification” 1985/2, s. 193-218; I.C. Lerman, Comparing partitions (mathematical and statistical aspects), [w:] red. H.H. Bock, Classification and Related Methods of Data Analysis. Springer 1988, s. 121-131; M. Meila, Comparing Clusterings - an axiomatic view, ICML '05: Proceedings of the $22^{\text {nd }}$ International Conference on Machine Learning 2007, s. 577-584; S. Wagner, D. Wagner, Comparing Clusterings - An Overview, Technical Report 2006-04. Faculty of Informatics, Universität Karlsruhe 2007.

${ }^{9}$ A. Sokołowski, Metoda porównywania wyników podziału zbioru skończonego, XII Konferencja Naukowa Ekonometryków, Statystyków i Matematyków Akademii Ekonomicznych Polski Południowej, Karpacz 1976; streszczenie w: „Przegląd Statystyczny” 1976/365.
} 
Brak danych dla wszystkich regionów chorwackich (4), zamorskich francuskich (Guadeloupe, Martinique, Guyane, Réunion)i hiszpańskich (Ciudad Autónoma de Ceuta, Ciudad Autónoma de Melilla) spowodował, że analizy prowadzono dla 264 z 272 regionów UE szczebla NUTS $2^{10}$.

W każdym z opisanych obszarów wrażliwości algorytm postępowania polegał na ${ }^{11}$ : ustaleniu listy zmiennych; wyznaczeniu median cech na podstawie wszystkich lat obserwacji;,,standaryzacji” (przez podzielenie przez medianę - medianę danych przestrzenno-czasowych ${ }^{12}$ ); wykorzystanie taksonomii dynamicznej, w tym ustalenie liczby grup - poprzez poddanie kostki danych (obiekty - regiony rozpatrywane łącznie dla wszystkich lat razem) analizie zapomocą metody Wardaiostateczną klasyfikację metodą k-średnich; interpretacja wyników, w tym analiza merytoryczno-czasowa dla krajów i geograficzno-czasowa dla grup.

W dalszej części artykułuprzedstawiono wyniki klasyfikacji w poszczególnych obszarach wrażliwości.

\subsection{Wyniki klasyfikacji w obszarze wrażliwości na kryzys - gospodarka}

Zastosowanie opisanego algorytmu postepowania pozwoliło na podział zbioru regionów UE szczebla NUTS 2 pod względem wrażliwości na kryzys w obszarze gospodarki na pięć grup. Zestawienia regionów przypisanych do wydzielonych klas oraz graficzną prezentację (mapy) otrzymanych podziałów przedstawiono w pracyMarkowskiej i in ${ }^{13}$, a zmienne wykorzystane w ocenie wrażliwości na kryzys w tym obszarze to:

- $\quad \mathrm{PKB}$ per capita w PPS - (PKB);

- globalny(suma regionalna) PKB w mln euro - tempo zmian (TZ_PKB);

- nakłady inwestycje na pracującego w tys. euro (IN);

- $\quad$ nakłady inwestycyjne (suma regionalna) w mln euro - tempo zmian (TZ_IN).

Krótką charakterystykę klas, pod względem wartości średnich zmiennych jest następująca:

- grupa trzecia - najwyższe PKB i inwestycje, relatywnie dobre tempo wzrostu, zważywszy, że przyrosty te są z wysokiego poziomu;

- $\quad$ grupa druga - najniższy poziom zmiennych,ale i najwyższe tempa wzrostu;

- grupa pierwsza i czwarta - niemal identyczne poziomy, ale o ile w grupie pierwszej przyrosty są ujemne, o tyle grupa czwarta ma dobre tempa wzrostu,

\footnotetext{
${ }^{10}$ Regions in the European Union. Nomenclature of territorial unit for statistics NUTS 2010/EU27,Methodologies and Working Papers, European Commission, Luxembourg 2011.

${ }^{11}$ M. Markowska, D. Strahl, Wykorzystanie klasyfikacji dynamicznej do identyfikacji wrażliwości na kryzys ekonomiczny unijnych regionów szczebla NUTS 2, [w:] Taksonomia, red. M. Walesiak, K. Jajuga, Prace Naukowe Uniwersytetu Ekonomicznego we Wrocławiu nr 385, Wrocław 2015, s. 166-177.

${ }^{12}$ Zalety wykorzystanej standaryzacji: pozostawia znak tempa zmian - ujemny to pogorszenie, plus to poprawa; sprowadza wszystkie zmienne do jednakowej ważności i chociaż formalnie nie jest to system ważenia, to można powiedzieć, że w początkowym etapie tempa oryginalne są ważone wagami 1/Me. Ponadto pozostawia wartości odstające zdecydowanie różniące się od pozostałych (nie powodują sztucznej kompresji rozkładu jak w wypadku dzielenia przez odchylenie standardowe).

${ }^{13}$ M. Markowska, D. Strahl, A. Sokołowski, M. Sobolewski, Klasyfikacja dynamiczna regionów Unii Europejskiej szczebla NUTS 2 z uwagi na wrażliwość na kryzys ekonomiczny (obszar: zmiany w gospodarce), [w:] Problemy rozwoju regionalnego i lokalnego, red. M. Markowska, D. Głuszczuk, A. Sztando, Prace Naukowe Uniwersytetu Ekonomicznego we Wrocławiu nr 393, Wrocław 2015, s. 32-44.
} 
- $\quad$ grupa piąta - niskie poziomy zmiennych (choć nie najniższe) i ich gwałtowny spadek.

Zestawienia średnich $\mathrm{w}$ grupach wraz $\mathrm{z}$ ich liczebnością zamieszczono w tabelach $1 \mathrm{i}$ 2., a zmiany liczebności klas w latach zilustrowano na rysunku 1.

Tabela 1. Liczba obiekto-okresów wgrupach i wartości średnich - obszar wrażliwości: gospodarka

\begin{tabular}{|c|c|c|c|c|c|c|}
\hline \multirow{2}{*}{$\begin{array}{c}\text { Numer } \\
\text { grupy }\end{array}$} & Liczba & Procent & \multirow{2}{*}{ PKB } & \multirow{2}{*}{ TZ_PKB } & \multirow[b]{2}{*}{ IN } & \multirow{2}{*}{ TZ_IN } \\
\hline & \multicolumn{2}{|c|}{ obiekto-okresów } & & & & \\
\hline 1 & 380 & 24,0 & 25035,79 & $-1,34$ & 12,96 & $-1,90$ \\
\hline 2 & 271 & 17,1 & 13483,39 & 6,24 & 4,64 & 13,67 \\
\hline 3 & 117 & 7,4 & 43250,43 & 4,17 & 19,56 & 9,58 \\
\hline 4 & 569 & 35,9 & 25465,20 & 5,50 & 12,82 & 9,13 \\
\hline 5 & 247 & 15,6 & 19525,10 & $-4,33$ & 7,81 & $-19,35$ \\
\hline
\end{tabular}

PKB - PKB per capita w PPS;TZ_PKB - tempo zmian globalnego (regionalnego) PKB; IN nakłady inwestycje na pracującego w tys. euro; TZ_IN - tempo zmian nakładów inwestycyjnych (suma regionalna)

Źródło: opracowanie na podstawie:M.Markowska,D. Strahl,A. Sokołowski,M. Sobolewski, Klasyfikacja dynamiczna regionów Unii Europejskiej szczebla NUTS 2 z uwagi na wrażliwość na kryzys ekonomiczny (obszar: zmiany w gospodarce), [w:] Problemy rozwoju regionalnego i lokalnego, red. M. Markowska, D. Głuszczuk, A. Sztando, Prace Naukowe Uniwersytetu Ekonomicznego we Wrocławiu nr 393, Wrocław 2015, s. 32-44.

Tabela 2. Liczebność grup w latach - obszar wrażliwości: gospodarka

\begin{tabular}{|c|c|c|c|c|c|c|c|}
\hline Grupa & $\mathbf{2 0 0 6}$ & $\mathbf{2 0 0 7}$ & $\mathbf{2 0 0 8}$ & $\mathbf{2 0 0 9}$ & $\mathbf{2 0 1 0}$ & $\mathbf{2 0 1 1}$ & Razem \\
\hline 1 & 8 & 17 & 128 & 109 & 59 & 59 & 380 \\
\hline 2 & 58 & 54 & 46 & 2 & 60 & 51 & 271 \\
\hline 3 & 20 & 23 & 25 & 5 & 18 & 26 & 117 \\
\hline 4 & 173 & 170 & 26 & 0 & 107 & 93 & 569 \\
\hline 5 & 5 & 0 & 39 & 148 & 20 & 35 & 247 \\
\hline
\end{tabular}

Źródło: opracowanie na podstawie:M.Markowska,D. Strahl,A. Sokołowski,M. Sobolewski, Klasyfikacja dynamiczna regionów Unii Europejskiej szczebla NUTS 2 z uwagi na wrażliwość na kryzys ekonomiczny (obszar: zmiany w gospodarce), [w:] Problemy rozwoju regionalnego i lokalnego, red. M. Markowska, A. Sztando, M. Obrębalski, Prace Naukowe Uniwersytetu Ekonomicznego we Wrocławiunr 393, Wrocław 2015, s. 32-44.

Rysunek 1. Liczebność grup w latach 2006-2011 - obszar wrażliwości: gospodarka

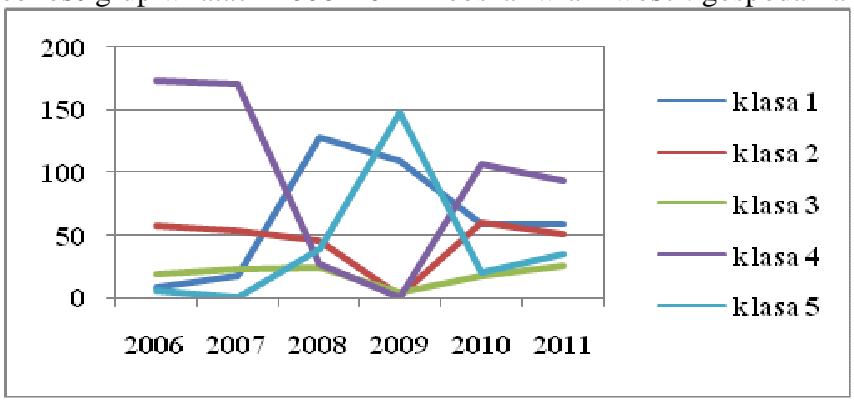

Źródło: opracowanie na podstawie danych z tabeli 2. 
Z danych w tabeli 2 i na rysunku 1 wynika, że rok 2008 stanowił początek przełomu dla zmian w liczebności klas - do roku 2012 trwały przetasowania w przynależności regionów do utworzonych skupień. Znamienne jest zwłaszcza przejmowanie regionów przez klasę pierwszą w roku 2008 i piątą w roku 2009 kosztem pozostałych klas.

\subsection{Wyniki klasyfikacji w obszarze wrażliwości na kryzys - rynek pracy}

W ocenie wrażliwości na kryzys w obszarze rynek pracy wykorzystano cztery zmienne ${ }^{14}$.

- $\quad$ stopa zatrudnienia (SZ);

- $\quad$ tempo zmian stopy zatrudnienia (TZ_SZ);

- $\quad$ stopa bezrobocia (SB - destymulanta);

- tempo zmian stopy bezrobocia, przeliczone na stymulantę (wartość dodatnia to spadek bezrobocia) (TZ_SB).

Charakterystyka otrzymanych grup jest następująca ${ }^{15}$ :

- $\quad$ grupa pierwsza - najwyższa stopa zatrudnienia i najniższe bezrobocie, a stopy mają pozytywną tendencję: zwiększające się zatrudnienie (średnie dodatnie tempo zmian stopy zatrudnienia) i zmniejszające się bezrobocie;

- grupa druga - najniższa stopa zatrudnienia i relatywnie wysokie bezrobocie;

- grupa trzecia - dobra sytuacja co do poziomu stóp (druga pozycja wśród grup), jednak druga pozycja (ale druga najgorsza) w wypadku temp pogarszania się tych wskaźników;

- grupa czwarta - najlepsze ze wszystkich grup tempa poprawy;

- grupa piąta - najszybsze spadki zatrudnienia i bezrobocia; najwyższe bezrobocie i prawie najniższa stopa zatrudnienia.

Zestawienia średnich w grupach i ich liczebność zawarto w tabelach 3 i 4, natomiast zmieniające się liczebności klas w latach zilustrowano na rysunku 2.

Tabela 3. Liczba obiekto-okresów w grupach i wartości średnich-obszar: rynek pracy

\begin{tabular}{|c|c|c|c|c|c|c|}
\hline \multirow{2}{*}{$\begin{array}{c}\text { Numer } \\
\text { grupy }\end{array}$} & Liczba & Procent & \multirow{2}{*}{ SZ } & \multirow{2}{*}{ TZ_SZ } & \multirow{2}{*}{ SB } & \multirow{2}{*}{ TZ_SB } \\
\hline & \multicolumn{2}{|c|}{ obiekto-okresów } & & & & \\
\hline 1 & 602 & 38,0 & 70,92 & 1,09 & 5,37 & 8,63 \\
\hline 2 & 247 & 15,6 & 55,78 & $-0,63$ & 11,88 & $-5,44$ \\
\hline 3 & 361 & 22,8 & 68,38 & $-1,54$ & 6,76 & $-24,41$ \\
\hline 4 & 291 & 18,4 & 61,67 & 2,87 & 9,58 & 12,51 \\
\hline 5 & 83 & 5,2 & 58,53 & $-5,23$ & 15,91 & $-45,60$ \\
\hline
\end{tabular}

SZ - stopa zatrudnienia; TZ_SZ - tempo zmian stopy zatrudnienia;

SB - stopa bezrobocia; TZ_SB - tempo zmian stopy bezrobocia

Źródło: opracowanie na podstawie:M.Markowska, D. Strahl, A. Sokołowski, M. Sobolewski,

Klasyfikacja dynamiczna regionów Unii Europejskiej szczebla NUTS 2 z uwagi na

wrażliwość na kryzys ekonomiczny w obszarze: rynek pracy,,Zarządzanie i Marketing,

Zeszyty Naukowe Politechniki Rzeszowskiej” 2015 (w druku).

\footnotetext{
${ }^{14}$ M. Markowska, D. Strahl, A. Sokołowski, M. Sobolewski, Klasyfikacja dynamiczna regionów Unii Europejskiej szczebla NUTS 2 z uwagi na wrażliwość na kryzys ekonomiczny w obszarze: rynek pracy,,Humanities and SocialSciences, Zeszyty Naukowe Politechniki Rzeszowskiej” 2015 (w druku). ${ }^{15}$ Ibidem.
} 
Tabela 4.Liczebność grup w latach - obszar: rynek pracy

\begin{tabular}{|c|c|c|c|c|c|c|c|}
\hline Grupa & $\mathbf{2 0 0 6}$ & $\mathbf{2 0 0 7}$ & $\mathbf{2 0 0 8}$ & $\mathbf{2 0 0 9}$ & $\mathbf{2 0 1 0}$ & $\mathbf{2 0 1 1}$ & Razem \\
\hline 1 & 115 & 142 & 128 & 26 & 78 & 113 & 602 \\
\hline 2 & 30 & 23 & 28 & 44 & 61 & 61 & 247 \\
\hline 3 & 30 & 21 & 50 & 153 & 75 & 32 & 361 \\
\hline 4 & 88 & 78 & 54 & 10 & 24 & 37 & 291 \\
\hline 5 & 1 & 0 & 4 & 31 & 26 & 21 & 83 \\
\hline
\end{tabular}

Źródło: opracowanie na podstawie:M.Markowska, D. Strahl, A. Sokołowski, M. Sobolewski, Klasyfikacja dynamiczna regionów Unii Europejskiej szczebla NUTS 2 pod wzgledem wrażliwości na kryzys ekonomiczny w obszarze rynek pracy,,Humanities and SocialSciences, Zeszyty Naukowe Politechniki Rzeszowskiej” 2015 (w druku).

Rysunek 2. Liczebność grup w latach 2006-2011 - obszar wrażliwości: rynek pracy

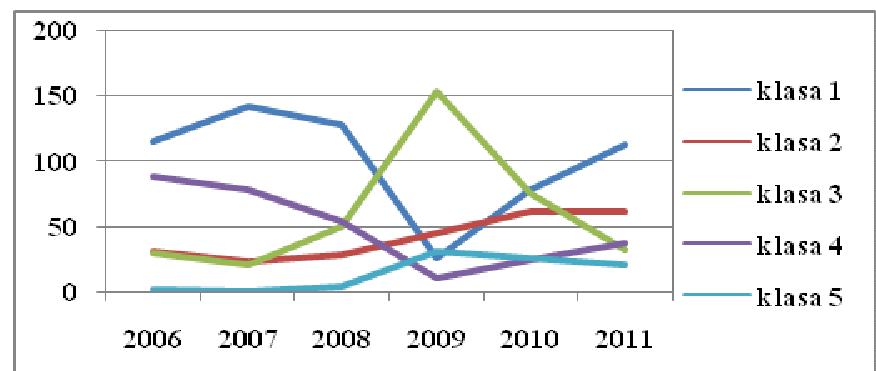

Źródło: opracowanie na podstawie danych z tabeli 4

Dlakolejnego obszaru wrażliwości najbardziej spektakularne zmiany w liczebności klas nastąpiły w 2009r., zwłaszcza w wypadku klasy pierwszej (spadek o niemal 100) i trzeciej (wzrosto ponad 100 regionów).

\subsection{Wyniki klasyfikacji w obszarze wrażliwości na kryzys - gospodarstwa domowe}

W obszarze: gospodarstwa domowe jako zmiennediagnostyczne wykorzystano ${ }^{16}$ :

- $\quad$ wynagrodzenia w mln euro w regionie (globalnie) - tempo zmian (TZ_WYN);

- $\quad$ przeciętne wynagrodzenie w tys. euro na pracującego w regionie (WYN);

- dochód rozporządzalny na głowę w gospodarstwie domowym w PPS - tempo zmian (TZ_DOCH);

- $\quad$ dochód rozporządzalny na głowę w gospodarstwie domowym w PPS (DOCH).

Otrzymane - w wyniku zastosowania opisanego wcześniej algorytmu -klasy można scharakteryzować następująco:

- grupa pierwsza - niski średni poziom zmiennych, ale wysokie tempo ich wzrostu;

- grupa druga - wysoki średni poziom zmiennych, ale niskie tempo ich wzrostu;

\footnotetext{
${ }^{6} \mathrm{M}$. Markowska, Ocena wrażliwości na kryzys gospodarstw domowych $w$ unijnych regionach - analiza przestrzenno-czasowa, [w:] Problemy rozwoju regionalnego i lokalnego, red. M. Markowska, D. Głuszczuk i A. Sztando, Prace Naukowe Uniwersytetu Ekonomicznego we Wrocławiu nr 393, Wrocław 2015, s. 53-66.
} 
- grupa trzecia - przeciętny średni poziom wynagrodzeń i dochodów oraz niskie tempo ich wzrostu;

- grupa czwarta - bardzo wysokie średnie wynagrodzenia i wysoki dochód rozporządzalny;

- $\quad$ grupa piąta - gigantyczny spadek wynagrodzeń.

Wartości średnich $\mathrm{w}$ grupach oraz liczebność grup przedstawiono w tabelach $5 \mathrm{i}$ 6.Rysunek 3 pozwala ocenić zmieniające się liczebności klas w latach.

Tabela 5. Liczba obiekto-okresów w grupach i wartości średnich - obszar: gospodarstwa domowe

\begin{tabular}{|c|c|c|c|c|c|c|}
\hline \multirow{2}{*}{$\begin{array}{c}\text { Numer } \\
\text { grupy }\end{array}$} & Liczba & Procent & \multirow[b]{2}{*}{ WYN } & \multirow[b]{2}{*}{ TZ_WYN } & \multirow[b]{2}{*}{ DOCH } & \multirow[b]{2}{*}{ TZ_DOCH } \\
\hline & \multicolumn{2}{|c|}{ obiekto-okresów } & & & & \\
\hline 1 & 190 & 12,1 & 7,20 & 10,21 & 7,19 & 11,55 \\
\hline 2 & 1038 & 66,0 & 32,16 & 2,17 & 16,57 & 2,14 \\
\hline 3 & 306 & 19,5 & 15,33 & 2,25 & 10,68 & 2,13 \\
\hline 4 & 25 & 1,6 & 81,13 & 3,03 & 20,58 & 2,12 \\
\hline 5 & 13 & 0,8 & 1,25 & $-92,76$ & 12,06 & $-8,76$ \\
\hline
\end{tabular}

WYN - przeciętne wynagrodzenie w tys. euro na pracującego w regionie; TZ_WYN - tempo zmian globalnego wynagrodzenia (suma w regionie); DOCH - dochód rozporządzalny na głowę w gospodarstwie domowym w PPS; TZ_DOCH - tempo zmian dochodu rozporządzalnego na głowę w gospodarstwie domowym

Źródło: opracowanie na podstawie:M. Markowska, Ocena wrażliwości na kryzys gospodarstw domowych $w$ unijnych regionach - analiza przestrzenno-czasowa, [w:] Problemy rozwoju regionalnego i lokalnego, red. M. Markowska, D. Głuszczuk i A. Sztando, Prace Naukowe Uniwersytetu Ekonomicznego we Wrocławiu nr 393, Wrocław 2015, s. 53-66.

Tabela 6.Liczebność grup w latach - obszar: gospodarstwa domowe

\begin{tabular}{|c|c|c|c|c|c|c|c|}
\hline Grupa & $\mathbf{2 0 0 6}$ & $\mathbf{2 0 0 7}$ & $\mathbf{2 0 0 8}$ & $\mathbf{2 0 0 9}$ & $\mathbf{2 0 1 0}$ & $\mathbf{2 0 1 1}$ & Razem \\
\hline 1 & 43 & 46 & 35 & 22 & 36 & 8 & 190 \\
\hline 2 & 170 & 173 & 175 & 173 & 174 & 173 & 1038 \\
\hline 3 & 48 & 41 & 50 & 65 & 49 & 65 & 318 \\
\hline 4 & 3 & 4 & 4 & 4 & 5 & 5 & 25 \\
\hline 5 & 0 & 0 & 0 & 0 & 0 & 13 & 13 \\
\hline
\end{tabular}

Źródło: opracowanie na podstawie:M. Markowska, Ocena wrażliwości na kryzys gospodarstw domowych $w$ unijnych regionach - analiza przestrzenno-czasowa, [w:] Problemy rozwoju regionalnego i lokalnego, red. M. Markowska, D. Głuszczuk i A. Sztando, Prace Naukowe Uniwersytetu Ekonomicznego we Wrocławiu nr 393, Wrocław 2015, s. 53-66.

Rysunek 3. Liczebność grup w latach 2006-2011 - obszar wrażliwości: gospodarstwa domowe

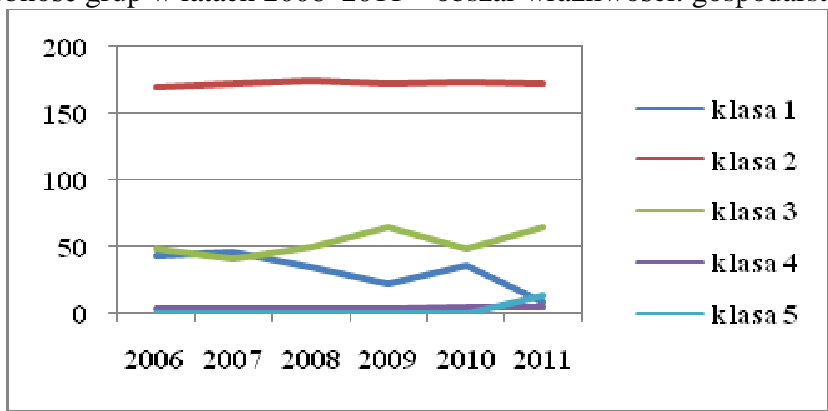

Źródło: opracowanie na podstawie danych z tabeli 6. 
W obszarze gospodarstwa domowe zmiany liczebności klas w latach nie były tak gwałtowne jak w opisanych wcześniej obszarach wrażliwości na kryzys ekonomiczny.

\section{OCENA ZGODNOŚCI PODZIALÓW}

Opisane przesunięcia regionów między klasami, które wystąpiły głównie w latach 2008 i 2009,mogą stwarzać wrażenie, że podobieństwa otrzymanych podziałów nie będą znaczne. Oceny zgodności podziałów dokonano w dwóch ujęciach. W pierwszym klasyfikacja została przeprowadzona dla obiekto-okresów - otrzymano po jednym grupowaniu dla każdej sfery: rynek pracy, gospodarka, gospodarstwa domowe, macierz podobieństwa przedstawiono $\mathrm{w}$ tabeli 7 . Wdrugimzaś podobieństwo podziałów badano dla każdego roku osobno (tab.8).

Tabela 7. Miary podobieństwa podziałów otrzymanych z taksonomii dynamicznej

\begin{tabular}{|c|c|c|c|}
\hline Wyszczególnienie & $\begin{array}{c}\text { Rynek pracy } \\
\text { (RP) }\end{array}$ & $\begin{array}{c}\text { Gospodarka } \\
\text { (G) }\end{array}$ & $\begin{array}{c}\text { Gospodarstwa } \\
\text { domowe (GD) }\end{array}$ \\
\hline Rynek pracy (RP) & 1 & 0,6653 & 0,5153 \\
\hline Gospodarka (G) & 0,6653 & 1 & 0,6027 \\
\hline Gospodarstwa domowe (GD) & 0,5153 & 0,6027 & 1 \\
\hline
\end{tabular}

Źródło: opracowanie własne.

Oceniając pierwsze - ujęcie całościowe - można stwierdzić, że najmocniejsze podobieństwo dynamicznych klasyfikacji dotyczy rynku pracy i gospodarki, a najsłabsze - rynku pracy i sfery gospodarstw domowych. Wydaje się, że na wyciagnięcie ciekawszych wniosków pozwala ujęcie drugie.

Można zbadać dynamikę podobieństwa klasyfikacji. Dla trzech par sfer oszacowano trendy (rys. 4). Mimo bardzo małej liczby obserwacji aż dwa z nich okazały się istotne statystycznie, na poziomie $\alpha=0,10$.

Podobieństwo podziałów dla rynku pracy oraz dla gospodarki istotnie wzrosło w badanym okresie według równania trendu (2). Tendencja ta byłaby jeszcze bardziej wyraźna, gdyby nie kryzys z 2009r.

$$
W_{\mathrm{t}}=0,4757+0,0327 t
$$

Wartość $p$ dla współczynnika kierunkowego trendu wyniosła 0,0570 .

Tabela 8. Miary podobieństwa klasyfikacji w poszczególnych latach

\begin{tabular}{|c|c|c|c|c|c|c|c|}
\hline 2006 & RP & G & GD & 2007 & RP & G & GD \\
\hline RP & 1 & 0,5251 & 0,7231 & RP & 1 & 0,5389 & 0,6009 \\
\hline G & 0,5251 & 1 & 0,5829 & G & 0,5389 & 1 & 0,6800 \\
\hline GD & 0,7231 & 0,5829 & 1 & GD & 0,6009 & 0,6800 & 1 \\
\hline 2008 & RP & G & GD & 2009 & RP & G & GD \\
\hline RP & 1 & 0,6007 & 0,6030 & RP & 1 & 0,5150 & 0,5748 \\
\hline G & 0,6007 & 1 & 0,6377 & G & 0,5150 & 1 & 0,5442 \\
\hline GD & 0,6030 & 0,6377 & 1 & GD & 0,5748 & 0,5442 & 1 \\
\hline 2010 & RP & $\mathbf{G}$ & GD & 2011 & RP & $\mathbf{G}$ & GD \\
\hline RP & 1 & 0,6679 & 0,5797 & RP & 1 & 0,6940 & 0,6405 \\
\hline G & 0,6679 & 1 & 0,6600 & G & 0,6940 & 1 & 0,6256 \\
\hline GD & 0,5797 & 0,6600 & 1 & GD & 0,6405 & 0,6256 & 1 \\
\hline
\end{tabular}

G - gospodarka; GD - gospodarstwa domowe; RP - rynek pracy

Źródło: opracowanie własne. 
Rysunek 4. Trendy miar podobieństwa podziałów
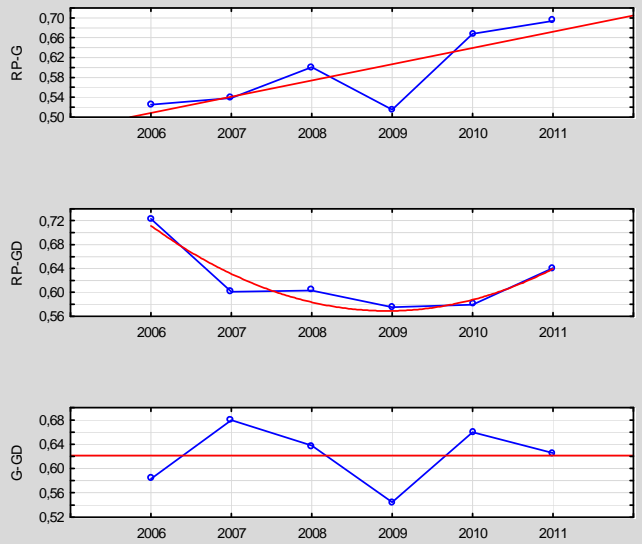

Źródło: opracowanie własne.

Podobieństwo podziałów ze względu na rynek pracy oraz gospodarkę zmniejszało się do 2009 r., natomiastpóźniejta tendencja sięodwróciła. Spowodowało to, że rozsądnym modelem zmian okazał się trend paraboliczny o równaniu (3):

$$
W_{t}=0,8252-0,1302 t+0,0165 t^{2}
$$

Wartość p dla współczynnika przy zmiennej t wyniosła 0,0159, dla współczynnika przy t ${ }^{2}$ zaś była równa 0,0206 .

Pod względempodobieństwa podziałów gospodarki i gospodarstw domowych nie stwierdzono istotnej tendencji.

\section{PODSUMOWANIE}

W obu ujęciach (ocena w każdym roku i zdynamizowana) wskaźniki zgodności otrzymanych podziałów w zakresie obszarów wrażliwości na kryzys ekonomiczny regionów UE szczebla NUTS 2 byływ wyższe niż 0,5. Przy czym dla podejścia całościowego otrzymano miary w przedziale od 0,515 (rynek pracy - gospodarstwa domowe) do 0,665 (rynek pracy - gospodarka), a w wypadku poszczególnych lat (w nawiasach podano obszary):

- $\quad$ od 0,525 (RP-G) do 0,723 (RP-GD) w 2006r.;

- $\quad$ od 0,539 (RP-G) do 0,680 (G-GD) w 2007 r.;

- $\quad$ od 0,601 (RP-G) do 0,638 (G-GD) w 2008 r.;

- $\quad$ od 0,515 (RP-G) do 0,575 (RP-GD) w 2009 r.;

- $\quad$ od 0,580 (RP-GD) do 0,668 (RP-G) w 2010 r.;

- $\quad$ od 0,626 (G-GD) do 0,694 (RP-G) w 2011 r.

Należy wskazać w tym miejscu, że o ile w czterech pierwszych latach najmniejsze podobieństwo uzyskano dla obszarów: rynek pracy i gospodarka, o tyle w dwóch ostatnich latach dla obszarów tych wskaźniki zgodności były najwyższe. Znamienne jest także wzrastanie - mimo wskazanych wcześniej przesunięć regionów pomiędzy skupieniami - w kolejnych latach (poza 2009 r.) najniższego poziomu wskaźnika zgodności podziałów. 
W kontekście otrzymanych wyników wyzwaniem dla badaczy staje się poszukiwanie czynników determinujących odrębne ,ścieżki” reakcji, poddawanie się bądź odporność na zjawiska kryzysowe regionów.

\section{LITERATURA}

[1] Arabie P., Hubert L., Comparing Partitions,,Journal of Classification”1985/2, s. $193-218$.

[2] Briguglio L., Cordina G., Farrugia N., Vella S., Economic Vulnerability and Resilience: Concepts and Measurements. Oxford Development Studies"2009/37, 3,s. 229-247.

[3] Churski P., Borowczak A., Dolata M., Dominiak J., Hauke J., KoneckaSzydłowska B., Perdał R., Rekomendacje dotyczace zasobów informacyjnych oraz wskaźnikowania zjawisk spoteczno-ekonomicznych w badaniach regionalnych, Biuletyn KPZK PAN, Warszawa2014.

[4] Lerman I.C., Comparing partitions (mathematical and statistical aspects),[w:]red.H.H.Bock, Classification and Related Methods of Data Analysis. Springer1988, s. 121-131.

[5] Markowska M., Dynamiczna taksonomia innowacyjności regionów, WydawnictwoUniwersytetu Ekonomicznego we Wrocławiu, Monografie i Opracowania 221, Wrocław2012.

[6] Markowska M., Ocena zależności między rozwojem inteligentnym a odpornościa na kryzys ekonomiczny $w$ wymiarze regionalnym - przeglad badań,[w:] Gospodarka regionalna w teorii i praktyce, red.D. Strahl, A. Raszkowski i D. Głuszczuk, Prace Naukowe Uniwersytetu Ekonomicznego we Wrocławiu nr 333, Wrocław2014, s. 22-32.

[7] Markowska M., Ocena wrażliwości na kryzys gospodarstw domowych w unijnych regionach - analiza przestrzenno-czasowa, [w:] Problemy rozwoju regionalnego i lokalnego, red. M. Markowska, D. Głuszczuk, A. Sztando, Prace Naukowe Uniwersytetu Ekonomicznego we Wrocławiu nr 393, Wrocław 2015, s. 53-66.

[8] Markowska M., The vulnerability of regions to economic crisis - measurement problems,[w:] Regional economy and policy. Territories and cities, red.P. Hlavacek, P. Olsova, Jan Evangelista Purkyne University in Usti nad Labem Usti nad Labem 2014, 38-47.

[9] Markowska M., Strahl D., Sensitivity to economic crisis of the EU regions assessment of measurement possibilities,"ZeszytyNaukoweUniwersytetuEkonomicznego w Krakowie”2015 (w druku).

[10]Markowska M., Strahl D., Wykorzystanie klasyfikacji dynamicznej do identyfikacji wrażliwości na kryzys ekonomiczny unijnych regionów szczebla NUTS 2, [w:] Taksonomia, red. M. Walesiak, K. Jajuga, Prace Naukowe Uniwersytetu Ekonomicznego we Wrocławiu nr 385, Wrocław 2015, s. 166-177.

[11]Markowska M., Strahl D., Sokołowski A., Sobolewski M., Klasyfikacja dynamiczna regionów Unii Europejskiej szczebla NUTS 2 z uwagi na wrażliwość na kryzys ekonomiczny (obszar: zmiany w gospodarce), [w:] Problemy rozwoju regionalnego i lokalnego, red.M. Markowska, D. Głuszczuk, A. Sztando, Prace 
Naukowe Uniwersytetu Ekonomicznego we Wrocławiu nr 393, Wrocław 2015, s. 32-44.

[12]Markowska M., Strahl D., Sokołowski A., Sobolewski M., Klasyfikacja dynamiczna regionów Unii Europejskiej szczebla NUTS 2 pod względem wrażliwości na kryzys ekonomiczny w obszarze rynek pracy,,Humanities and SocialSciences, Zeszyty Naukowe Politechniki Rzeszowskiej”2015(w druku).

[13] Masik G., Uwarunkowania $i$ instrumenty wspierajace odporność gospodarcza miast $i$ regionów, referatna konferencji „Polityka miejska. Wyzwania, doświadczenia, inspiracje”, Warszawa 25-26.06.2013, 2013, http://www.euroreg.uw.edu.pl/media/prezentacje_konferencja_polityka_miejska/ _2_grzegorz_masik.pdf (dostęp: 25.09.2014).

[14]Meila M., Comparing Clusterings - an axiomatic view, ICML '05: Proceedings of the $22^{\text {nd }}$ International Conference on Machine Learning 2007, s. 577-584.

[15]Regions in the European Union. Nomenclature of territorial unit for statistics NUTS 2010/EU-27,Methodologies and Working Papers, European Commission, Luxembourg 2011.

[16]Sokołowski A., Metoda porównywania wyników podziału zbioru skończonego, XII Konferencja Naukowa Ekonometryków, Statystyków i Matematyków Akademii Ekonomicznych Polski Południowej, Karpacz1976; streszczenie w:,,Przegląd Statystyczny” 1976/365.

[17] Sokołowski A., Denkowska S., Salamaga M., Fijorek K., Rozkłady miar podobieństwa podziatu zbioru skończonego, Uniwersytet Ekonomiczny w Krakowie, Kraków2010(maszynopis).

[18]Strahl D., Sokołowski A., Propozycja podejścia metodologicznego do oceny zależności między inteligentnym rozwojem a wrażliwością na kryzys ekonomiczny $w$ wymiarze regionalnym,[w:] Problemy rozwoju regionalnego $i$ lokalnego, red.E. Sobczak, B. Bal-Domańska,M.Obrębalski, Prace Naukowe Uniwersytetu Ekonomicznego we Wrocławiu nr 331, Wrocław2014, s. 181-190.

[19]Wagner S., Wagner D., Comparing Clusterings - An Overview, Technical Report 2006-04, Faculty of Informatics, Universität Karlsruhe2007.

[20] Wrażliwość polskich regionów na wyzwania wspótczesnej gospodarki. Implikacje dla polityki rozwoju regionalnego, red. K. Gawlikowska-Hueckel, J. Szlachta, Oficyna a Wolters Kluwer business, Warszawa 2014.

\section{SPATIAL-TEMPORAL CLUSTER ANALYSIS IN THE ASSESSMENT OF THE EUROPEAN UNION NUTS 2 REGIONS' SENSITIVITY TO CRISIS IN THE AREAS OF ECONOMY, LABOUR MARKET AND HOUSEHOLDS - COMPARATIVE ANALYSIS OF THE CLASSIFICATION RESULTS}

The study presents the comparison of spatial-temporal cluster analysis results conducted separately in the particular areas of sensitivity to crisis. The areas of sensitivity to crisis suggested in the assessed classifications are as follows: economy, regional labour market and households.

Dynamic classification represents the classification method applied in the compared approaches, in which the analysed objects, in each year of the study, are referred to as separate taxonomic units. The European Union NUTS 2 regions constituted the objects covered by the study. The conducted analysis covered the period 2005-2011. After 
determining the rate of changes for numerous variables the classifications in particular sensitivity areas were performed based on the variables from the period 2006-2011.

The method for comparing division results of a finite set suggested by A. Sokołowski was used in comparing the results of obtained classifications. In accordance with this method the division compatibility coefficient - normalized in the range $[0 ; 1]-$ takes the higher values the more similar are the divisions. The similarity of divisions was assessed in terms of each year (for the division compatibility indicators in particular years the occurring trends were also presented) as well as based on a combined (dynamized) approach.

The obtained results indicate extensive similarities in the obtained classifications. In a dynamic approach the indicators present the level of 0,52 in the areas of regional labour market and households, up to 0,67 in the areas of economy and regional labour market. The comparisons conducted for each year also confirm the lowest division indicator at the level of 0,52 (labour market and economy in 2009), whereas the highest one - 0,72 (labour market and households in 2006).

Keywords: spatial-temporal cluster analysis, vulnerability area, economic crisis, NUTS 2 regions

DOI:10.7862/rz.2015.hss.32

Przesłano do redakcji: marzec 2015

Przyjęto do druku: październik 2015 